\title{
Rancang Bangun Aplikasi Jelajah Virtual Panorama Berbasis Web Pada Universitas PGRI Madiun
}

\author{
Muhammad Syaiful Anwar \\ Universitas PGRI Madiun \\ Program Studi Teknik Informatika \\ muhammadsyaiful99@gmail.com,
}

\begin{abstract}
Abstrak
Universitas PGRI Madiun merupakan salah satu perguruan tinggi unggulan di Jawa Timur. Untuk memudahkan masyarakat terutama calon mahasiswa baru, diperlukan sebuah aplikasi yang dapat menyajikan informasi mengenai lokasi dan fasilitas yang ada. Aplikasi jelajah virtual ini dirancang untuk mengatasi permasalahan tersebut. Dengan memanfaatkan gambar panorama yang telah disesuaikan, sehingga pengguna aplikasi dapat merasakan pengalaman berkunjung ke Universitas PGRI Madiun secara online terasa realistis. Metode perancangan yang digunakan dalam penelitian ini adalah metode Waterfall. Hasil dari penelitian ini berupa sebuah aplikasi jelajah virtual berupa halaman web yang dapat diakses dari manapun selama ada koneksi internet. Dengan adanya aplikasi ini diharapkan minat calon mahasiswa baru Universitas PGRI Madiun dari luar daerah Madiun makin meningkat.
\end{abstract}

\section{Kata kunci:Virtual Tour, Panorama, Universitas PGRI Madiun}

\section{PENDAHULUAN}

Informasi seputar Universitas PGRI Madiun yang tersedia secara online saat ini hanya terbatas pada pemberitaan seputar kegiatan kampus dan mahasiswa saja. Hal ini mengakibatkan calon mahasiswa baru yang berasal dari luar wilayah Madiun tidak memiliki gambaran secara detail mengenai wilayah kampus yang akan ditempatinya. Dengan adanya masalah ini diperlukan sebuah aplikasi yang dapat mengatasi permasalahan tentang informasi seputar wilayah Universitas PGRI Madiun. Aplikasi jelajah virtual panorama berbasis web menjadi solusi yang strategis dalam hal ini. Dengan memanfaatkan foto 360 derajat, pengguna dapat merasakan sensasi nyata berkunjung ke Universitas PGRI Madiun tanpa datang secara langsung. Perancangan dan pembangunan serta implementasi dari aplikasi jelajah virtual panorama berbasis web ini diharapkan dapat menambah ketertarikan calon mahasiswa baru terhadap Universitas PGRI Madiun.

Berdasarkan uraian di atas, penulis menggunakan beberapa penelitian terdahulu sebagai acuan perancangan sistem, diantaranya penelitian Falani dkk
(2016) yang berjudul "Implementasi Sistem Virtual Tour Berbasis E-Panorama Untuk Pengenalan Kampus Universitas Narotama Surabaya". Pada penelitian Falani dkk (2016) di atas menggunakan perangkat lunak krPano sebagai media untuk pengolahan objek gambar 360 . Sedangkan dalam penelitian ini menggunakan perangkat lunak berbasis web menggunakan bahasa PHP dan JSON.

\section{KAJIANTEORI Jelajah Virtual}

Falani dkk (2016) memaparkan bahwa jelajah virtual atau virtual tour merupakan suatu metode penggabungan teknik fotografi dan teknologi informasi yang berfungsi untuk memberikan informasi secara interaktif dan menyeluruh dari suatu lokasi baik dalam ruangan (indoor) maupun luar ruangan (outdoor). Jelajah virtual juga dapat dimanfaatkan sebagai media promosi atau mengenalkan suatu lokasi kepada masyarakat umum mengenai suatu lokasi.

Daud (2016) menyatakan bahwa jelajah virtual atau virtual tour merupakan simulasi dari sebuah lokasi yang terdiri dari beberapa foto yang digabung menjadi satu, sehingga 
menghasilkan sudut pandang 360 derajat dan dapat memberikan kesan seakanakan berada ditempat tersebut.

\section{Panorama}

Falani (2016) menyatakan bahwa panorama merupakan kumpulan beberapa gambar yang saling berkaitan sehingga menghasilkan sudut pandang yang lebih luas.Yadi (2014) berpendapat bahwa panorama merupakan salah satu jenis teknik fotografi yang menampilkan hasil atau output gambar atau foto yang bersudut pandang lebih luas dari gambar atau foto biasa.

PHP

Nurmiati (2015) menjelaskan bahwa PHP : Hypertext Preprocessor atau biasa disebut dengan PHP adalah salah satu bahasa pemrograman web yang bersifat open source atau sumber terbuka. Kode PHP dapat digabungkan dengan kode HTML maupun kode penyusun website lainnya untuk membentuk suatu halaman web yang dinamis.

JSON

Herdiana (2014) mengungkapkan bahwa JSON atau JavaScript Object Notation merupakan suatu format pertukaran data yang ringan, sederhana, mudah dibaca, ditulis maupun dimengerti oleh manusia, serta mudah diterjemahkan dan dibuat oleh komputer secara otomatis (generate).

\section{Kerangka Berfikir}

Berikut ini merupakan kerangka pemikiran dari penelitian ini:
Dalam topik yang dibahas pada penelitian ini, ditemukan permasalahan mengenai kurangnya informasi yang berkaitan mengenai lokasi atau wilayah Universitas PGRI Madiun yang mengungkap secara detail.

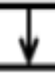

Untuk pelaksanaan penelitian dan menyelesaikan masalah yang ditemukan di atas, peneliti menggunakan metode Waterfall karena pendekekatan yang diterapkan sesuai dengan permasalahan yang dihadapi.

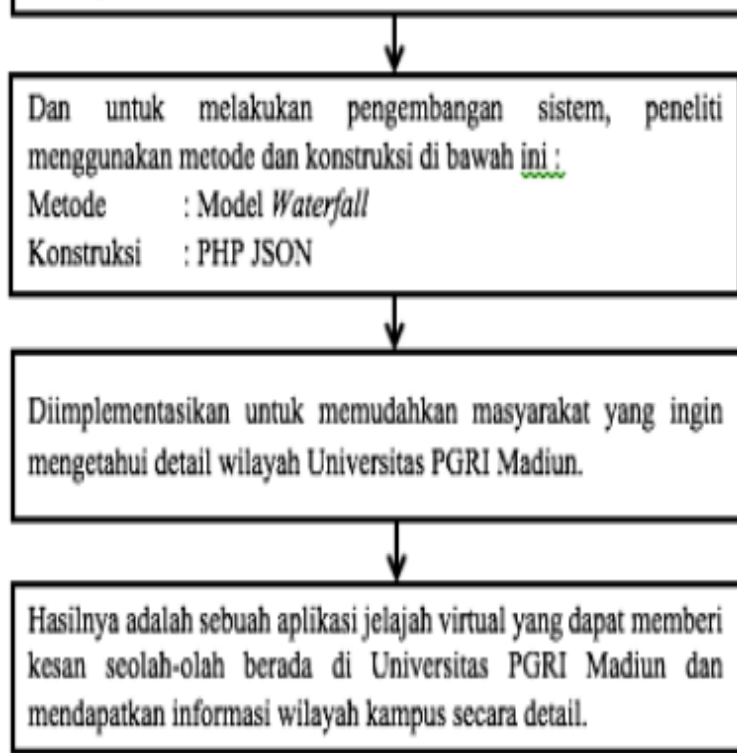

Gambar 1. Bagan Kerangka Berfikir

\section{METODE PENELITIAN}

Model penelitian yang digunakan pada penelitian adalah menggunakan metode Waterfall. Menurut Whitten (dalam Yogha dkk, 2016), “Waterfall adalah model yang sederhana dengan aliran sistem yang linier yang dimana output dari setiap tahap merupakan input bagi tahap selanjutnya".

Berikut gambaran metode waterfall :

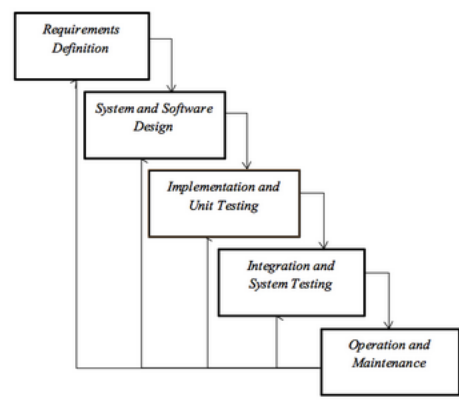

Gambar2. MetodeWaterfall 


\section{TEMPAT DAN WAKTU PENELITIAN}

Untuk menghasilkan sebuah penelitian dengan data dari hasil yang tepat, maka dibutuhkan tempat yang memiliki kesesuaian dengan rancangan aplikasi yang di bangun. Adapun tempat yang sesuai dijadikan obyek penelitian di Universitas PGRI Madiun dengan metode pengembangan sistem Waterfal. Penelitian ini membutuhkan waktu 4 bulan yaitu dimulai dari tanggal 1 April 2018 sampai dengan 31 Juli 2018.

\section{HASIL DAN PEMBAHASAN}

1. Diagram Use Case Pengguna

Diagram use case yang dibangun terdiri dari satu aktor sebagai pengguna aplikasi dan terdapat dua use case yaitu menampilkan daftar lokasi dan memilih titik lokasi yang tersedia. Berikut ini adalah diagramnya:

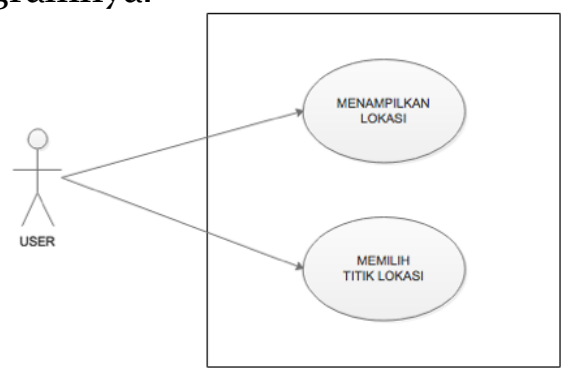

Gambar 3.Diagram Use Case Pengguna

2. Diagram Use Case Administrator Administrator memiliki peran untuk melakukan desain dan manajemen pengolahan data gambar panorama berupa scene dan hotspot yang sudah dikumpulkan. Berikut ini diagram untuk administrator :

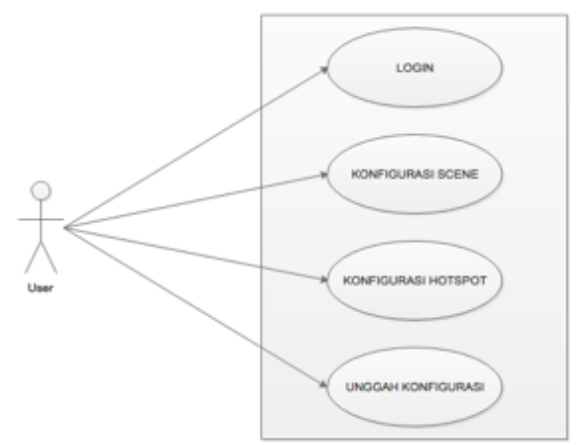

Gambar 4.Diagram Use Case Administrator

\section{IMLEMENTASI}

Aplikasijelajah virtual panorama ini memiliki tampilan antar muka pengguna yang telah diimplementasikan pada gambar dan penjelasan berikut :

1. TampilanPengguna

a. Tampilan Utama Pengguna

Tampilan utama ketika pengguna membuka alamat aplikasi melalui perambaan web.

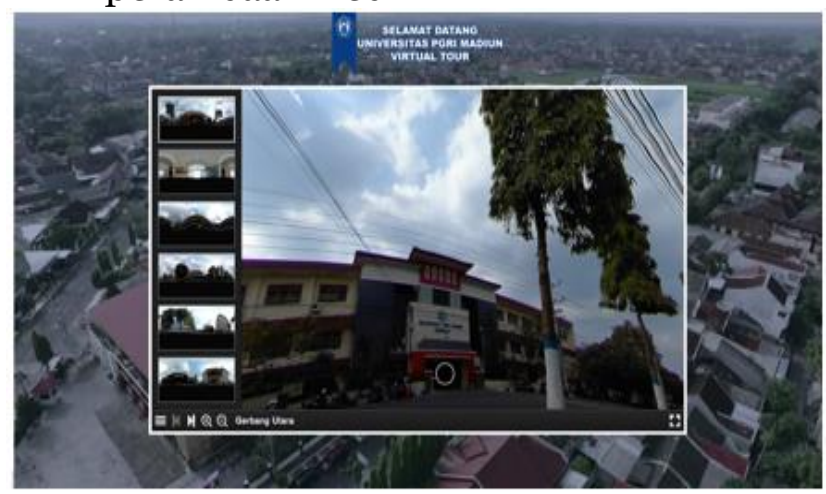

Gambar 5. Tampilan Tugas

\section{Tampilan Administrator}

a. Tampilan Login Administrator Tampilan ketika administrator login kesistem.

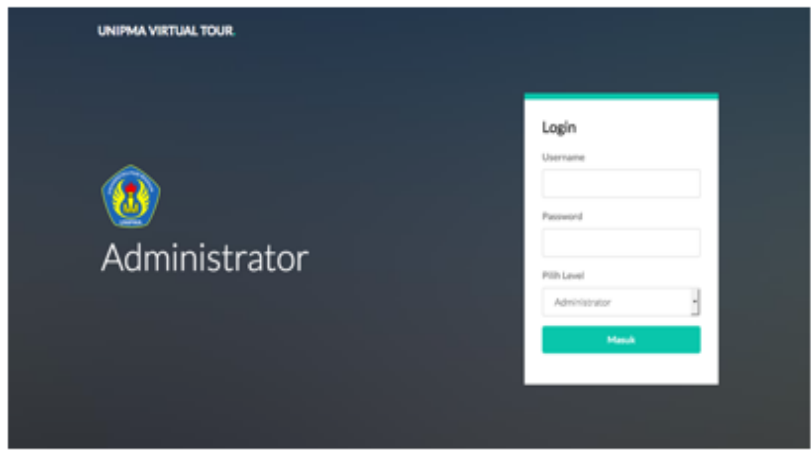

Gambar 6. Tampilan Login Administrator

b. Tampilan Panel Administrator Tampilan panel konfigurasi aplikasi administrator.

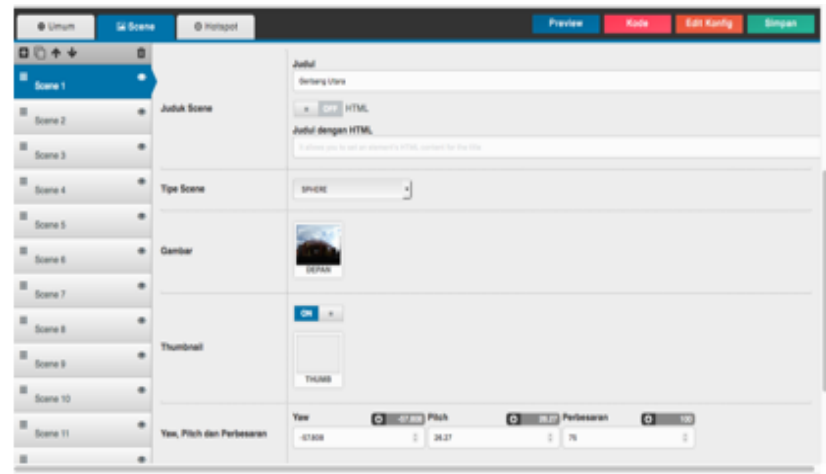

Gambar 7. Tampilan Panel Administrator 


\section{KESIMPULAN}

Dari hasil penelitian ini menghasilkan sebuah aplikasi jelajah virtual panorama berbasis web pada Universitas PGRI Madiun. Aplikasi ini berguna untuk membantu dan mempermudah masyarakat terutama calon mahasiswa baru untuk lebih mengenal lingkungan Universitas PGRI Madiun secara detail. Selain itu juga dapat dijadikan media promosi untuk meningkatkan daya tarik Universitas PGRI Madiun.

\section{DAFTAR PUSTAKA}

A. Z. Falani, H. A. S. Ramadan dan E. Setiawan. 2016. "Implementasi Sistem Virtual Tour Berbasis EPanorama Untuk Pengenalan Kampus Universitas Narotama Surabaya," Jurnal Insand Comtech, vol. 1, no. 1, p. 11.
E. Nurmiati. 2015. “Analisis Dan Perancangan Web Server Pada Handphone," Studia Informatika: Jurnal Sistem Informasi, vol. 5, no. 2 , p. 3.

F. R. Daud, V. Tulenan dan X. B. N. Najoan. 2016. "Virtual Tour Panorama 360 Derajat Kampus Universitas Sam Ratulangi Manado," E-journal Teknik Informatika, vol. 8, no. 1, p. 1.

Y. Herdiana. 2014. "Aplikasi Rumus Matematika SMA Berbasis Mobile," Jurnal Ilmiah Komputer dan Informatika (KOMPUTA), vol. 1, no. 1, p. 2. 